\title{
EFFECTS OF HIGH WATER SALINITY AND BETAINE SUPPLEMENTATION ON THE INCIDENCE OF PULMONARY HYPERTENSION IN BROILER CHICKENS
}

\author{
M.A.M. Sayed \\ Department of Poultry Production, Faculty of Agriculture, Assiut University, Assiut, Egypt, 71515
}

Received: $1 / 2 / 2017$

\begin{abstract}
SUMMARY
The effects of betaine supplementation on water consumption, stress measures and incidence of pulmonary hypertension induced by drinking saline water in broilers $(n=180)$ during summer were evaluated in a $2 \times 3$ factorial arrangement of treatments comprising 2 levels of betaine $(0$ and $500 \mathrm{mg} / \mathrm{l})$ and 3 levels of $\mathrm{NaCl}(0,4$ and $7 \mathrm{~g} / \mathrm{l}$ ) added to drinking water. The results indicated that broilers provided with saline water had higher hematocrits, $\mathrm{H} / \mathrm{L}$ ratio in blood and greater plasma $\mathrm{Na}^{+}$, glucose and cholesterol concentrations $(P<0.05)$. Betaine supplementation failed to attenuate the osmotic stress caused by drinking saline water. Variation in drinking water salinity resulted in significant betaine $\times$ drinking water interactions for water consumption. Regardless of betaine supplementation, drinking saline water resulted in kidney and heart hypertrophy and increased the right and left ventricle weights to the body weight ratios ( $R V / B W$ and $L V / B W)$, increased the number of mortalities and incidence of ascites syndrome. The increase in the right ventricle to total ventricle weights $(\mathrm{RV} / \mathrm{TV})$ was evident only in the $0.7 \% \mathrm{NaCl}$ group. The results suggest that betaine influenced drinking behaviour in broilers provided with saline water but failed to reduce the osmotic stress and the incidence of pulmonary hypertension.
\end{abstract}

Keywords: Organic osmolyte, water salinity, water consumption, ascites, broilers

\section{INTRODUCTION}

Huge economic losses take place every year due to high mortality rates caused by ascites. It is estimated that $5 \%$ of broilers produced annually suffer from ascites syndrome to death (Balog, 2003). Many factors contribute to the developing of ascites in broiler chickens. Hypoxia caused by poor shed ventilation or raising the birds at high altitudes results in increased blood flow to the lungs and increased hematocrit levels which elevates the viscosity of blood. This situation leads to increased resistance to blood flow, pulmonary vasoconstriction, increased cardiac output and eventually incidence of pulmonary hypertension (Mirsalimi et al., 1993).

The continuous genetic selection for rapid growth rate and better feed efficiency has produced faster growing broilers but with higher metabolic rates which make the cardiopulmonary system incapable of fulfilling the increased demand of oxygen by the tissues. These improvements in growth rate and feed efficiency make modern broilers more susceptible to develop ascites (Baghbanzadeh and Decuypere, 2008).

In poultry, excessive salt intake results in expansion of blood volume, increased cardiac output, increased blood flow through the lungs and reduction of erythrocyte deformability, which ultimately leads to induction of pulmonary hypertension (Julian, 1987 and Mirsalimi et al., 1993). Pulmonary hypertension results in right ventricular hypertrophy, right ventricular dilation and valvular hypertrophy and insufficiency. These events eventually lead to right ventricular failure (Julian, 1987; Mirsalimiet al., 1993; Xiang et al., 2004 and Zhang et al., 2013). Moreover, high levels of $\mathrm{Na}^{+}$in drinking water can result in left ventricle hypertrophy which suggests the occurrence of systemic hypertension and increased work load on both sides of the heart (Julian, 1987).

Insufficiency of the left atrioventricular valve causes regurgitation of blood flow to the left atrium during the ventricular systole which inevitably leads to pulmonary hypertension (Olkowski et al., 2001). Ascitic broilers show signs of severe dilation of both right and left ventricular chambers, thinning of ventricular muscle wall and heart valve pathology (Olkowski et al., 1997, 1998).

Broilers cannot tolerate high sodium levels in their plasma and they lack the ability to concentrate urine. In order to get rid of excess sodium, broilers must increase the glomerular filtration rate which does not accommodate the increase in plasma sodium levels. The increased blood volume and tension add pressure on the kidney and cause renal hypertrophy (Mirsalimi et al., 1993).

Kalmar et al. (2010) reported lower number of birds suffering from ascites and significant decreases in the incidence of pulmonary hypertension in broilers raised at low temperature $\left(15^{\circ} \mathrm{C}\right)$ from 14 to 40 days of age when supplemented with $\mathrm{N}, \mathrm{N}-$ dimethylglycine.

N,N-dimethylglycine is an intermediary metabolite in cellular choline and betaine metabolism. Betaine is considered a highly efficient organic osmoprotectant that helps cells, particularly 
those of the kidney, to tolerate high osmotic pressure (Kettunen et al., 2001).

The objectives of the current study were to evaluate the effects of betaine supplementation on the pattern of water consumption, organs weights, stress measures and the incidence of pulmonary hypertension in broilers provided with saline water during the period 14 to 35 days of age.

\section{MATERIALS AND METHODS}

\section{Birds and management:}

The experimental work was carried out at the Poultry Research Farm, Faculty of Agriculture, Assiut University. Egypt.
One hundred and eighty Cobb broilers were allocated to groups and housed in deep litter pens. Broilers were raised under continuous lighting program and brooding temperatures starting at $32^{\circ} \mathrm{C}$ for the first week and then reducing the temperature to $30^{\circ} \mathrm{C}$ during the second week. From 2-5 weeks of age, broilers were exposed to the natural ambient temperatures as presented in Table 1. Birds were provided with a corn-soybean commercial diet (220 g protein $/ \mathrm{kg}, 3100 \mathrm{kcal} / \mathrm{kg}, 9 \mathrm{~g}$ calcium $/ \mathrm{kg}, 4.5 \mathrm{~g}$ available phosphorus $/ \mathrm{kg}$ ). At one week of age, birds were individually weighed, wing banded and allocated to 18 pens (10 bidrs/pen) according to body weight.

Table 1. Average maximum and minimum indoor ambient temperatures $\left({ }^{\circ} \mathrm{C}\right)$ during the weeks 3,4 and 5

\begin{tabular}{cccc}
\hline & Week 3 & Week 4 & Week 5 \\
\hline Maximum Temp $\left({ }^{\circ} \mathrm{C}\right)$ & 31.5 & 31.8 & 33.3 \\
Minimum Temp $\left({ }^{\circ} \mathrm{C}\right)$ & 26.4 & 27.2 & 28.6 \\
\hline
\end{tabular}

\section{Treatments:}

At two weeks of age, birds were assigned to 6 treatment groups (each with 3 replicates of 10 birds per pen) and provided with $\mathrm{NaCl}$ in drinking water at inclusion rates of 0,4000 and $7000 \mathrm{mg} / \mathrm{l}$ and each $\mathrm{NaCl}$ treatment was supplemented with betaine at inclusion rates of 0 or $500 \mathrm{mg} / \mathrm{l}$.

Experimental measurements and sample collection:

Mortality was monitored daily and necropsied to identify the incidence of ascites. Water consumption was recorded at 19, 25 and 31 days of age.

At 5 weeks of age, blood samples were collected in heparinized tubes from 6 birds per treatment from brachial vein for the determination of hematocrit (PCV), plasma sodium, cholesterol and glucose concentrations and H:L ratio. Samples were placed on ice and aliquots were made to determine PCV. The H:L ratios were evaluated by examining blood smears stained using Geimsa stain (GS500, Sigma Aldrich, St. Louis, MO). Leukocytes (heterophils, lymphocytes, monocytes, basophils, and eosinophils) were differentially counted as described by Gross and Siegel (1983). The H:L ratio was calculated by counting 100 cells and dividing the number of heterophils by the number of lymphocytes (Sayed and Downing, 2011).

Blood was centrifuged at $1,200 \times \mathrm{g}$ for $20 \mathrm{~min}$ at $4^{\circ} \mathrm{C}$ and plasma was collected. Plasma concentrations of cholesterol were measured using commercial clorometric kit (Cholesterol. Liquizyme CHOD-PAP; Egyptian Company for Biotechnology, Cairo. Egypt). Plasma glucose concentrations were measured using commercial clorometric kit (Glucose. Liquizyme GOD-PAP; Egyptian Company for Biotechnology, Cairo. Egypt). Absorbance was monitored using a spectrophotometer (Unico UV-2000, SpectraLab Scientific Inc., USA) set at a wavelength of $545 \mathrm{~nm}$. Plasma sodium concentrations were measured using a flame photometer (Jenway, Bibby Scientific Limited, Beacon Road, Stone, Staffordshire, ST15 OSA, UK).

Six birds per treatment were sacrificed to record the relative weights of kidney, liver, heart, lungs and spleen. Incidence of pulmonary hypertension and right ventricle failure (RVF) were assessed according to methods previously described (Julian et al., 1989; Xiang et al., 2004). The heart was stripped off the major vessels, the atria and fat. The right ventricle was separated from the left ventricle and septum. The RV and LV were weighed separately and combined (total ventricle; TV). Birds having the RV/TV ratio > 0.250 were considered pulmonary hypertensive and those having the RV/TV ratio $>0.290$ were classified as suffering from RVF.

\section{Statistical analysis:}

The data obtained were analyzed in a $2 \times 3$ factorial arrangement of treatments, with $\mathrm{NaCl}$ and betaine as the main factors. The data were analyzed by ANOVA using the GLM procedure of SAS (SAS Institute, 2013). When treatment effects were significant, differences between least square means were tested using Duncan's multiple-range test (Duncan, 1955), and the differences were considered significant at the level of $\mathrm{P}<0.05$. The data of the incidence of mortality was analysed using the chisquare test.

\section{RESULTS}

The effects of drinking saline water and betaine supplementation on water consumption $(\mathrm{ml} / \mathrm{bird}$ at 19, 25 and 31 days of age), heterophil to lymphocyte ratio, plasma sodium levels and plasma concentrations of cholesterol and glucose are shown in Table 2.

At 19 days of age, water consumption increased dramatically in broilers provided with saline water 
$(\mathrm{P}<0.005)$. This increase was continued in the

$\mathrm{NaCl}$ birds $(\mathrm{P}<0.001)$.

following days ( 25 and 31 days of age) only in $0.4 \%$

Table 2. Effect of saline water and betaine supplementation on water consumption (ml/bird) at 19, 25 and 31 days of age, heterophil to lymphocyte ratio $(\mathrm{H}: \mathrm{L})$ and plasma concentrations of sodium, cholesterol and glucose

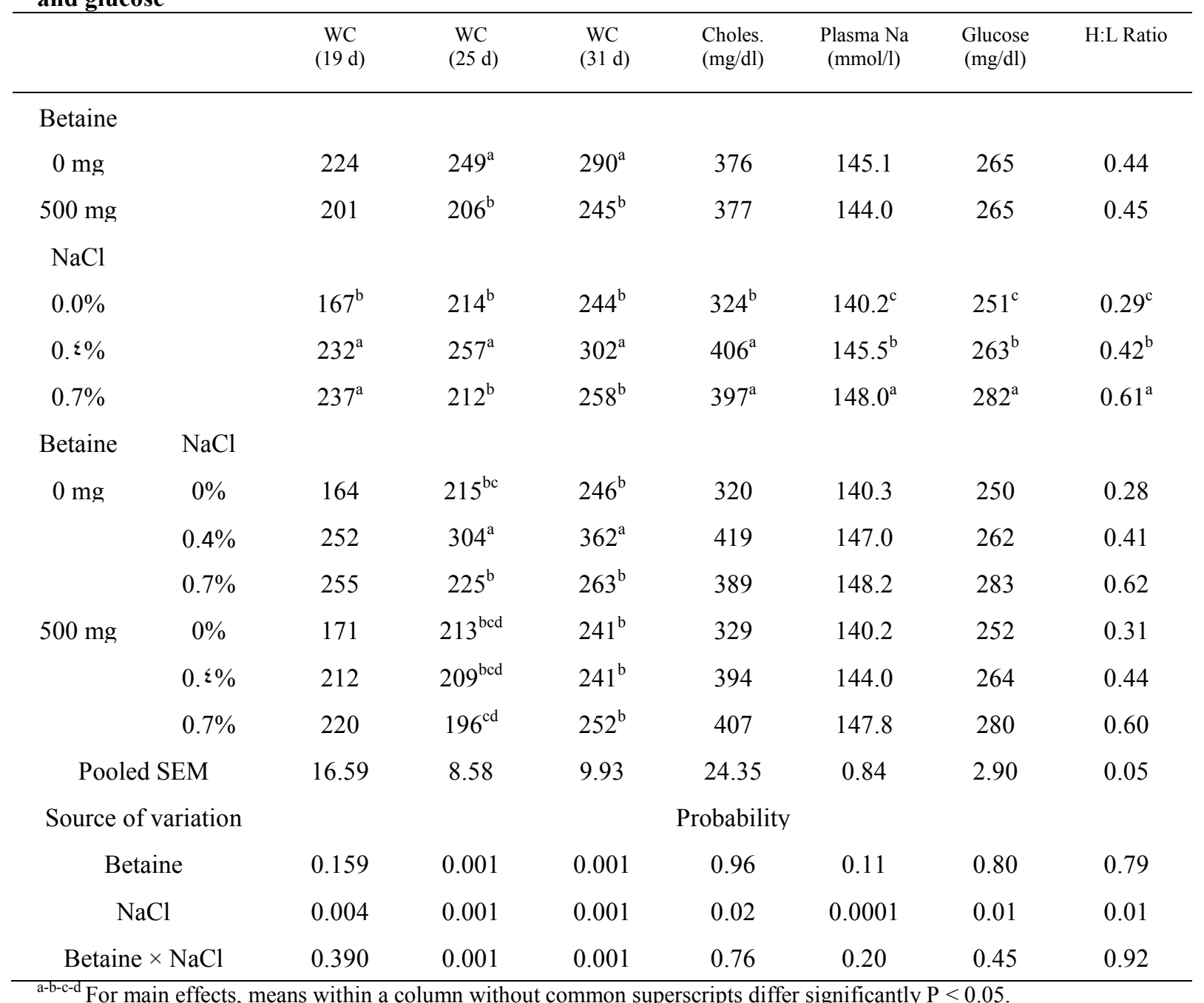

No significant changes were observed in water consumption at 19 days of age due to betaine supplementation $(\mathrm{P}>0.05)$. However, at 25 and 31 days of age, betaine addition resulted in a decrease in water consumption $(\mathrm{P}<0.001)$.

Significant saline water $\times$ betaine supplementation interactions for water consumption were observed at 25 and 31 days of age $(\mathrm{P}<0.001)$. From these interactions, it can be inferred that betaine has no effect on water consumption when tap water (no salt) was provided. Betaine significantly decreased water consumption only when saline water was offered.

Broilers provided with saline water had higher $\mathrm{H}: \mathrm{L}$ ratios $(\mathrm{P}<0.01)$ and higher concentrations of plasma cholesterol $(\mathrm{P}<0.05)$ and glucose $(\mathrm{P}<0.01)$ when compared with those provided with $0 \% \mathrm{NaCl}$ water. The H:L ratio and plasma glucose concentrations were higher in $0.7 \% \mathrm{NaCl}$ group than in $0.4 \% \mathrm{NaCl}$ birds.

No significant differences were observed in $\mathrm{H}: \mathrm{L}$ ratio and plasma glucose and cholesterol concentrations due to betaine supplementation $(\mathrm{P}>0.05)$.

Higher plasma sodium levels were noticed in broilers provided with saline water compared to those of birds offered tap water $(\mathrm{P}<0.0001)$. Broilers provided with $0.7 \% \mathrm{NaCl}$ had the highest plasma sodium levels compared to other treatment groups $(\mathrm{P}<0.0001)$.

The effect of drinking saline water and betaine supplementation on the incidence of pulmonary hypertension, right ventricular failure, ascites and mortality are shown in Table 3.

Mortality rate and the incidence of ascites were increased significantly by increasing $\mathrm{NaCl}$ levels in water $(\mathrm{P}<0.0001)$. Most cases of mortality and ascites occurred during the first 14 days of treatment. None of the dead birds from tap water with or without betaine supplementation were ascitic. Betaine supplementation had no effect on reducing the incidence of mortality and ascites in broilers provided with saline water. At 35 days of age, a sample of birds from each treatment group was 
sacrificed to assess the incidence of pulmonary hypertension and right ventricular failure. It was found that five birds (out of twelve) from groups provided with tap water with or without betaine were pulmonary hypertensive. Similarly, five birds (out of twelve) from groups provided with $0.4 \% \mathrm{NaCl}$ with or without betaine supplementation was recorded as pulmonary hypertensive. None of these birds were suffering from right ventricular failure. In groups provided with $0.7 \% \mathrm{NaCl}$ with or without betaine supplementation, eleven birds (out of twelve) were pulmonary hypertensive and two cases of them had right ventricular failure.

The effect of drinking saline water and betaine supplementation on internal organs' weight relative to body weight is presented in Table 4 .

Table 3. Effect of drinking saline water and betaine supplementation on incidence of pulmonary hypertension, right ventricular (RV) failure, total mortality and incidence of ascites

\begin{tabular}{|c|c|c|c|c|c|}
\hline \multicolumn{2}{|c|}{ Treatment } & $\begin{array}{c}\text { Pulmonary } \\
\text { hypertension }\end{array}$ & RV Failure & Total mortality & Incidence of Ascites \\
\hline \multicolumn{6}{|c|}{$\mathrm{NaCl}$ with or without bet. } \\
\hline \multicolumn{2}{|c|}{$0.0 \%$} & $5 / 12^{b}$ & $0 / 12^{b}$ & $5 / 60^{c}$ & $0 / 60^{c}$ \\
\hline \multicolumn{2}{|c|}{$0.4 \%$} & $5 / 12^{\mathrm{b}}$ & $0 / 12^{\mathrm{b}}$ & $15 / 60^{\mathrm{b}}$ & $6 / 60^{\mathrm{b}}$ \\
\hline \multicolumn{2}{|c|}{$0.7 \%$} & $11 / 12^{\mathrm{a}}$ & $2 / 12^{\mathrm{a}}$ & $31 / 60^{\mathrm{a}}$ & $14 / 60^{\mathrm{a}}$ \\
\hline $\mathrm{NaCl}$ & Betaine & & & & \\
\hline $0 \%$ & $0 \mathrm{mg}$ & $2 / 6^{\mathrm{b}}$ & $0 / 6^{\mathrm{b}}$ & $2 / 30^{c}$ & $0 / 30^{c}$ \\
\hline $0.4 \%$ & $0 \mathrm{mg}$ & $2 / 6^{b}$ & $0 / 6^{b}$ & $8 / 30^{b}$ & $3 / 30^{b}$ \\
\hline $0.7 \%$ & $0 \mathrm{mg}$ & $5 / 6^{\mathrm{a}}$ & $1 / 6^{\mathrm{a}}$ & $18 / 30^{\mathrm{a}}$ & $8 / 30^{a}$ \\
\hline $0 \%$ & $0.5 \mathrm{mg}$ & $3 / 6^{b}$ & $0 / 6^{\mathrm{b}}$ & $3 / 30^{c}$ & $0 / 30^{c}$ \\
\hline $0.4 \%$ & $0.5 \mathrm{mg}$ & $3 / 6^{b}$ & $0 / 6^{b}$ & $7 / 30^{b}$ & $3 / 30^{b}$ \\
\hline \multirow[t]{2}{*}{$0.7 \%$} & $0.5 \mathrm{mg}$ & $6 / 6^{\mathrm{a}}$ & $1 / 6^{\mathrm{a}}$ & $13 / 30^{\mathrm{a}}$ & $6 / 30^{a}$ \\
\hline & & \multicolumn{4}{|c|}{ Probability } \\
\hline \multicolumn{2}{|c|}{$\mathrm{NaCl}$ with or without bet. } & 0.0001 & 0.0001 & 0.0001 & 0.0001 \\
\hline \multicolumn{2}{|c|}{$\mathrm{NaCl} \times$ betaine } & 0.0001 & 0.0001 & 0.0001 & 0.0001 \\
\hline
\end{tabular}

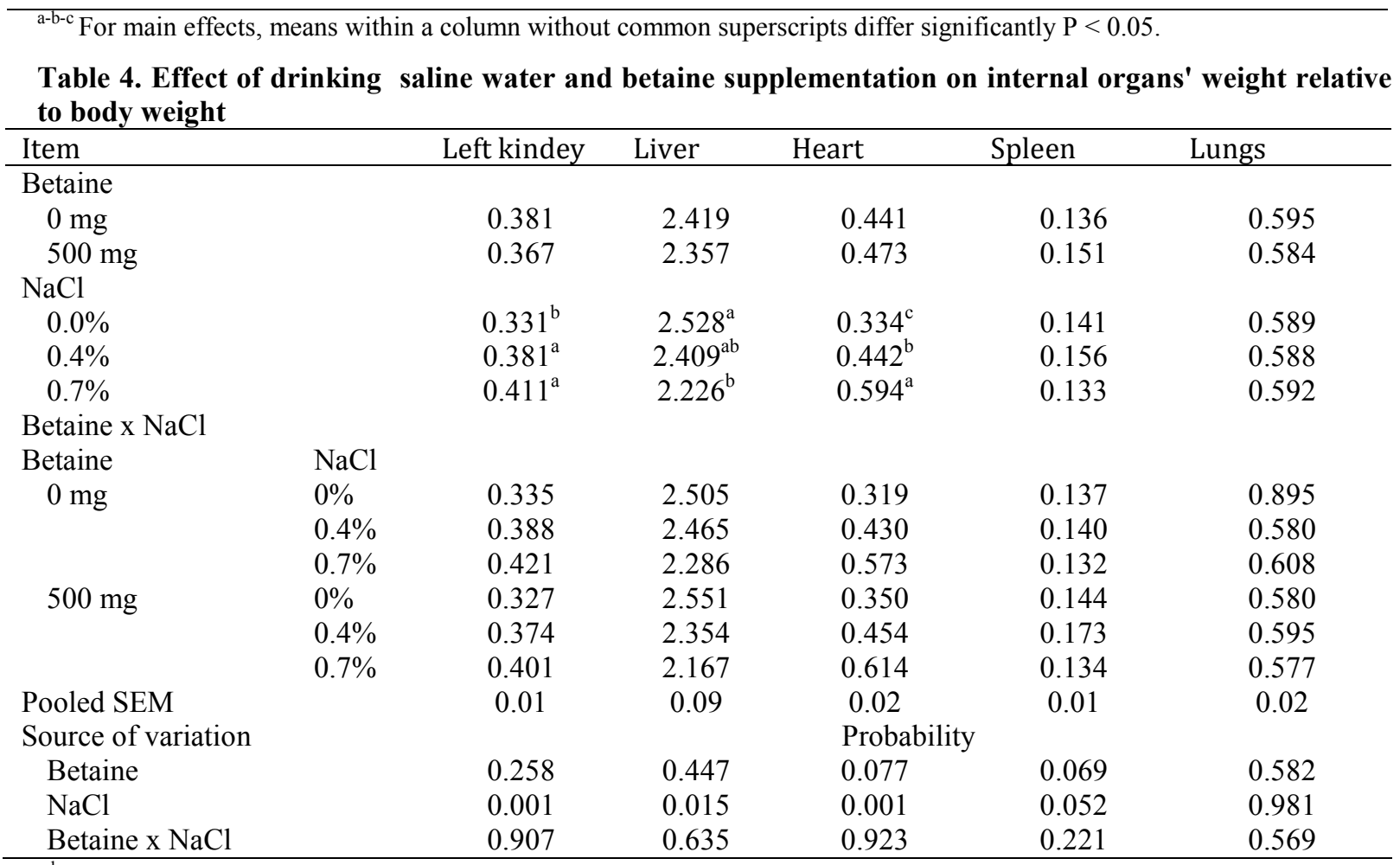

\footnotetext{
${ }^{\mathrm{a}-\mathrm{b}-\mathrm{c}}$ For main effects, means within a column without common superscripts differ significantly $\mathrm{P}<0.05$.
} 
Drinking saline water increased the relative weights of kidney $(\mathrm{P}<0.001)$ and heart $(\mathrm{P}<0.001)$. Broilers in $0.7 \% \mathrm{NaCl}$ group had smaller liver relative weights compared with those in $0 \% \mathrm{NaCl}$ $(\mathrm{P}=0.015)$. While, the relative liver weights in $0.4 \%$ $\mathrm{NaCl}$ birds were intermediate.

There was a tendency for broilers supplemented with betaine to have heavier heart $(\mathrm{P}=0.077)$ and spleen $(\mathrm{P}=0.069)$ relative weights. Neither saline water nor betaine had any effect on the lung relative weights $(\mathrm{P}>0.05)$.

The effects of drinking saline water and betaine supplementation on the relative weights of right, left and total ventricles, right ventricle to total ventricle weight ratio and packed cell volume are shown in Table (5).

In general, saline water increased the right and left ventricle relative weights and as a consequence, the total ventricle weight $(\mathrm{P}<0.001)$. The effects were more pronounced in the $0.7 \% \mathrm{NaCl}$ compared to $0.4 \% \mathrm{NaCl}$ groups. Birds in $0.7 \% \mathrm{NaCl}$ groups had higher RV/TV than those in $0.4 \%$ and $0 \% \mathrm{NaCl}$ groups $(\mathrm{P}<0.001)$. Broilers provided with saline water had higher PCV values than those in the $0 \%$ $\mathrm{NaCl}$ groups $(\mathrm{P}<0.001)$. Betaine supplementation had no effects on these parameters.

Table 5. Effect of Drinking saline water and betaine supplementation on relative weight of right (RV), left (LV) and total (TV) ventricles, right to total ventricle (RV/TV) weight ratio and packed cell volume (PCV)

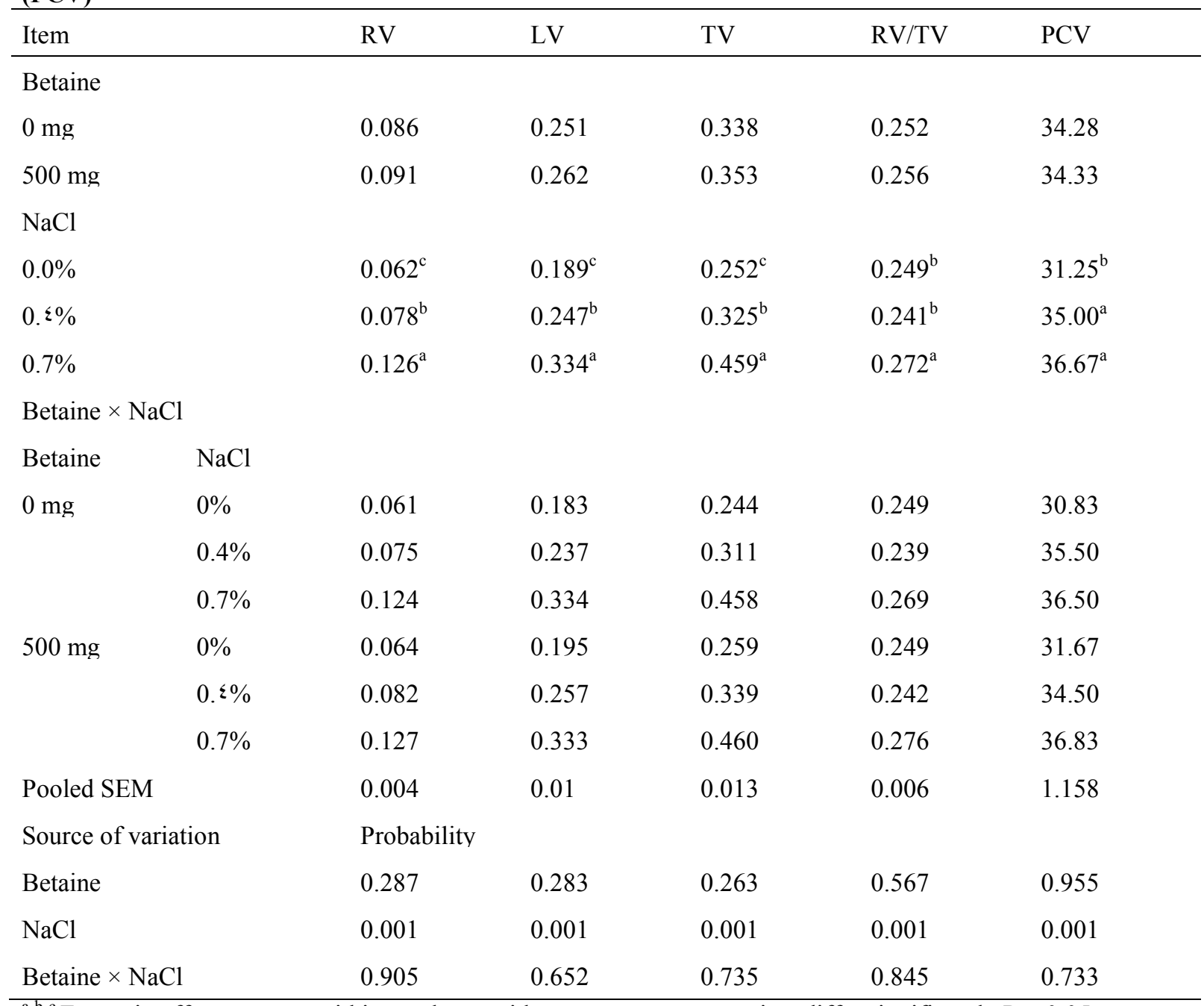

${ }^{\mathrm{a}-\mathrm{b}-\mathrm{c}}$ For main effects, means within a column without common superscripts differ significantly $\mathrm{P}<0.05$.

\section{DISCUSSION}

Providing electrolytes in the drinking water alters the birds' osmotic balance in a way that enhances thirst (Teeter and Belay, 1996). Drinking saline water increases sodium concentrations in plasma which is capable, at certain levels, of changing the osmolality of body fluids. The osmolality of the extracellular fluid is controlled primarily by the concentration of sodium and its attendant anions (Verbalis, 2003). The increased tonicity of the extracellular fluid increases the osmotic pressure on the body cells that may result in drawing water from the cells into the extracellular fluid. To prevent this, certain neurons (osmo- $\mathrm{Na}^{+}$ receptors) detects the concentration of sodium in extracellular fluid and triggers osmotic thirst to help restore the body fluids to a normal state (Stachenfeld, 
2008). In humans, a minimal change (2-3\%) in plasma tonicity is capable of inducing thirst (Stachenfeld, 2008).

In the current study, the addition of sodium chloride to drinking water at inclusion rates of $0.4 \%$ and $0.7 \%$ increased water consumption during the first few days of the treatment period as shown on day 19 . Similarly increasing water salinity by adding 1 and $2 \mathrm{~g} / \mathrm{L}$ to drinking water resulted in increased water consumption in broilers (Honarbakhsh et al., 2007). However, during the subsequent days (day 25 and 31), the enhanced drinking behavior was noted only in the $0.4 \% \mathrm{NaCl}$ group; while, birds provided with $0.7 \% \mathrm{NaCl}$ returned to water consumption rates comparable to those observed in the tap water groups. This decrease in water consumption which occurred after an initial increase in the $0.7 \% \mathrm{NaCl}$ group may suggest induction of an adaptive response due to a reduced ability to tolerate higher sodium levels in plasma.

Significant interactions between saline water and betaine supplementation for water consumption were observed at 25 and 31 days of age. From these interactions, it can be concluded that betaine substantially decreased water consumption only when saline water was provided.

To the best of our knowledge, such a decreasing effect of betaine on water consumption rate due to drinking saline water has not been reported before in literature. Only one paper reported on similar decreasing effects of betaine on water consumption in broiler chickens challenged by cocci exposure was presented by Teeter et al. (1999). The researchers observed a significant betaine $\times$ cocci exposure interaction for water consumption as cocci challenge elevated water consumption in the absence of betaine by $780 \%$, while the elevation in water consumption was reduced to only $47 \%$ when betaine was supplemented. One of the common signs of coccidial infection is diarrhea which would decrease extracellular fluid volume and stimulates thirst. The reduction in the elevated water consumption that occurred in the presence of betaine suggests its role in restoring the intestinal and extracellular water balance which, as a consequence, reduces water requirements and thirst.

To prevent water efflux, body cells rapidly respond to a hypertonic environment by accumulating inorganic ions (i.e. $\mathrm{K}^{+}$and $\mathrm{Na}^{+}$). However, lengthy periods of high concentration of inorganic ions can denature and inhibit the function of macromolecules (i.e. proteins). To help avoid this, cells internalize organic osmolytes via integral membrane proteins (Strange, 2004). The accumulation of these organic osmolytes modulates the environment tonicity inside the cells and prevents water flux without harming the cellular macromolecules (Alfieri et al., 2002).

Therefore, results of the current study suggests that betaine accumulation may have reduced osmotic shrinkage of central and peripheral osmosensory cells which resulted in a decreased signal transmission for osmotic thirst stimulation.

Drinking saline water was found to increase $\mathrm{H}: \mathrm{L}$ ratio and the concentrations of glucose and cholesterol in plasma. Betaine supplementation failed to attenuate the physiological response to the osmotic stress triggered by the addition of $\mathrm{NaCl}$ to tap water.

Stress increases the number of heterophils and decreases the numbers of lymphocytes (Gross and Siegel, 1983; Siegel, 1995 and Vleck et al., 2000). Results obtained here agree with those of Ahmed (2013) who observed elevated H:L ratios in broilers by increasing total dissolved solids (TDS) levels in drinking water. Moreover, Maxwell et al. (1986) reported increased heterophils at the expense of lymphocytes numbers in ascitic broilers compared to unaffected control birds.

Exposure to a wide variety of stressors was found to be associated with biochemical and metabolic changes. These metabolic changes include increases in plasma glucose, cholesterol, triglycerides and high density lipoprotein concentrations (Puvadolpirod and Thaxton, 2000). Therefore, the biochemical changes in cholesterol and glucose are used by some as indicators of stress in domestic poultry (Mumma et al., 2006).

Several studies have shown that exposure to stressful conditions can induce hyperglycemia and hypercholesterolemia in animals (Pare et al., 1973; Surwit et al., 1992 and Zardooz et al., 2006).

Mumma et al. (2006) suggested that as lipids are mobilized in a response to increased glucocorticoids secretion, they are broken down to nonesterified fatty acids which are converted to triglycerides in the liver. Then, triglycerides are transported by very-low density lipoproteins from the liver to adipose tissues and muscles where they are hydrolyzed by lipoprotein lipase. During this process, the very-low density lipoproteins are converted to cholesterol ester rich-low density lipoproteins.

The release of glucocorticoids is associated with promotion of glycemia in animals (Surwit et al., 1992 and Zardooz et al., 2006). This happens mainly by increasing glucose production in the liver (gluconeogenesis) and inducing a state of insulin resistance that acts to decrease glucose uptake in adipose tissues and skeletal muscle (Surwit et al., 1992; Dupont et al., 1999; Zardooz et al., 2006 and Zhao et al., 2009).

Drinking saline water significantly elevated sodium levels in plasma. This is a direct response of supplementing $\mathrm{NaCl}$ in drinking water. These results agree with those of Ahmad et al. (2006) who observed elevated plasma $\mathrm{Na}^{+}$concentrations following supplementation of broiler diets with different salts. The highest plasma sodium levels were noted in broilers provided with $0.7 \% \mathrm{NaCl}$. Although there was no significant interaction between saline water and betaine in plasma sodium concentrations, broilers provided with $0.4 \% \mathrm{NaCl}$ and betaine had numerically lower plasma sodium 
levels than those provided with $0.4 \% \mathrm{NaCl}$ without betaine supplementation (144.0 vs $147.0 \mathrm{mmol} / \mathrm{l}$, respectively). This could be due to the lower saline water consumption in birds supplemented with betaine.

Mortality rate was significantly increased in broilers provided with saline water $(25 \%$ and $51.6 \%$ for $0.4 \%$ and $0.7 \% \mathrm{NaCl}$ groups, respectively). These results are in agreement with those of Hayat et al. (1999) who reported an incidence of 22 and $90 \%$ mortality when broilers were supplemented with $\mathrm{NaHCO}_{3}$ at the rate of 8 and $10 \mathrm{~g} / \mathrm{L}$ in water, respectively. Similarly, supplementation with 7 to 10 $\mathrm{g} \mathrm{NaCl} / \mathrm{L}$ in the drinking water was associated with high mortality (up to 90\%) in chickens (Krista et al., 1961; and Sibbald et al., 1962).

No cases of ascites were observed in broilers provided with tap water with or without betaine. However, 10 and $23.3 \%$ of birds provided with $0.4 \%$ and $0.7 \% \mathrm{NaCl}$, respectively, had developed ascites syndrome. Betaine supplementation appeared to have no effect on reducing the incidence of ascites.

In general, saline water significantly increased the heart, RV, LV and TV relative weights. These results are in agreement with previous observations of Julian (1987), Mirsalimi et al. (1993), Xiang et al. (2004) and Zhang et al. (2013).

The RV/TV ratio, which has a direct relationship to pulmonary hypertension, was higher in broilers consumed $0.7 \% \mathrm{NaCl}$ compared to those of birds provided with tap water and $0.4 \% \mathrm{NaCl}$. Although $0.4 \% \mathrm{NaCl}$ treatment increased the $\mathrm{RV}$ relative weight compared to those of birds provided with tap water, the RV/TV ratio was comparable in both treatments. This can be attributed to the LV hypertrophy occurred in $0.4 \% \mathrm{NaCl}$ group which reduced the $\mathrm{RV} / \mathrm{TV}$ ratio and masked any differences between the $0.4 \% \mathrm{NaCl}$ and tap water groups. Similar results of LV hypertrophy affecting the RV/TV ratio in broilers provided with saline water was reported by Julian (1987).

No cases of RVF were recorded in tap water and $0.4 \% \mathrm{NaCl}$ (with or without betaine) groups. Two cases (out of twelve birds sacrificed) in the $0.7 \%$ $\mathrm{NaCl}$ (with or without betaine) groups were recorded as RVF. Betaine supplementation had no effect on the incidence of pulmonary hypertension and RVF.

Feeding broiler chickens diets containing $167 \mathrm{mg}$ $\mathrm{N}$, N-dimethylglycine sodium salt/kg was found to significantly decrease the incidence of pulmonary hypertension and numerically reduced fulminant ascites induced by exposing the birds to low temperature $\left(15^{\circ} \mathrm{C}\right)$ during the period $14-40$ days of age (Kalmar et al., 2010). It is well known that N, Ndimethylglycine, a derivative of the amino acid glycine, is an intermediary metabolite in cellular choline and betaine metabolism. The ameliorative effects of $\mathrm{N}$, N-dimethylglycine on reducing the incidence of pulmonary hypertension were attributed to its effect on fat metabolism by reducing nonesterified fatty acids in plasma. These nonesterified fatty acids induce vascular effects which can cause increased arterial pressure (Kalmar et al., 2010). However, the induction of pulmonary hypertension in the current study was imposed by different means which might explain the failure of betaine in reducing the incidence of pulmonary hypertension and ascites. Moreover, betaine supplementation tended to increase the heart relative weights $(\mathrm{P}=0.077)$

There was a significant increase in PCV values in broilers provided with saline water compared to those in tap water groups. These results are in line with those of Julian (1987) and Xiang et al. (2004). The increased PCV in turn increases blood viscosity and causes increased resistance to pulmonary blood flow leading to pulmonary hypertension (Chien et al., 1967 and Burton et al., 1968). Betaine supplementation was reported to decrease PCV in broiler chickens indicating a role that betaine plays in regulating blood volume (Honarbakhsh et al., 2007). However, in the current study, we could not observe any changes in PCV values due to betaine supplementation.

Drinking saline water had different effects on the relative weights of kidney, liver and lung. Broilers provided with saline water showed increased kidney/BW, decreased liver/BW and unchanged lung/BW relative weights when compared with those of tap water groups.

Similar results of enlarged kidneys in ascitic birds as a result of tubular and glomerular hypertrophy were previously reported (Sokkar et al., 1983; Maxwell et al., 1986; and Mirsalimi et al., 1993). Shrunken livers covered by a thin layer of semigelatinous material in ascites syndrome affected broilers were reported by Maxwell et al. (1986). Contrary to mammals, lungs in birds are rigid and do not expand and contract (Mirsalimi et al., 1993). This might explain the unaffected lung/BW relative weights in broilers consumed saline water despite the increased pulmonary pressure.

Broilers provided with $0.7 \% \mathrm{NaCl}$ in drinking water had a tendency to decrease spleen relative weights compared to those provided with tap water and $0.4 \% \mathrm{NaCl}$. On the other hand, betaine supplementation tended to increase spleen relative weights. These effects of saline water and betaine on the relative weight of spleen are difficult to interpret.

\section{CONCLUSION}

The results suggest that both betaine supplementation and the levels of $\mathrm{NaCl}$ in drinking water influenced drinking behaviour in broiler chickens. Betaine supplementation failed to attenuate the physiological response to the osmotic stress imposed by drinking saline water and had no effect on reducing the incidence of pulmonary hypertension, ascites and mortality.

\section{ACKNOWLEDGEMENT}

This work was funded by the Faculty of Agriculture, Assiut University, Assiut, Egypt. 


\section{REFERENCES}

Ahmad, T., T. Mushtaq, N. MahrUn, M. Sarwar, D.M. Hooge and M.A. Mirza, 2006. Effect of different non-chloride sodium sources on the performance of heat-stressed broiler chickens. British Poultry Science. 47: 249-256.

Ahmed, A.S., 2013. Performance and immune response of broiler chicks as affected by different levels of total dissolved solids in drinking water under hot arid environments. Animal Production Science. 53: 322-327.

Alfieri, R.R., A. Cavazzoni, P. G. Petronini, M A. Bonelli, A. E. Caccamo, A. F. Borghetti, and K. P. Wheeler, 2002. Compatible osmolytes modulate the response of porcine endothelial cells to hypertonicity and protect them from apoptosis. Journal of Physiology-London. 540: 499-508.

Baghbanzadeh, A. and E. Decuypere, 2008. Ascites syndrome in broilers: physiological and nutritional perspectives. Avian Pathology. 37: 117-126.

Balog, J. M., 2003. Ascites syndrome (Pulmonary hypertension syndrome) in broiler chickens: Are we seeing the light at the end of the tunnel? Avian and Poultry Biology Reviews. 14: 99-125.

Burton, R. R., E. L. Besch, and A. H. Smith, 1968. Effect of chronic hypoxia on the pulmonary arterial blood pressure of the chicken. The American journal of physiology. 214: 1438-42.

Chien, S., S. Usami, R. J. Dellenback, and M. I. Gregersen, 1967. Blood viscosity: influence of erythrocyte deformation. Science (New York, N.Y.) 157:827-9.

Duncan, D.B., 1955. Multiple range and multiple F. tests. Biometrics. 11: 1-42.

Dupont, J., M. Derouet, J. Simon, and M. Taouis, 1999. Corticosterone alters insulin signaling in chicken muscle and liver at different steps. Journal of Endocrinology. 162: 67-76.

Gross, W. B., and H. S. Siegel, 1983. Evaluation of the heterophil/lymphocyte ratio as a measure of stress in chickens. Avian diseases. 27: 972-9.

Hayat, J., D. Balnave, and J. Brake, 1999. Sodium bicarbonate and potassium bicarbonate supplements for broilers can cause poor performance at high temperatures. British Poultry Science. 40: 411-418.

Honarbakhsh, S., M. Zaghari, and M. Shivazad, 2007. Can Exogenous Betaine Be an Effective Osmolyte in Broiler Chicks under Water Salinity Stress?.Asian-Australasian Journal of Animal Science. 20:1729-1737

Julian, R. J., 1987. The effect of increased sodium in the drinking water on right ventricular hypertrophy, right ventricular failure and ascites in broiler chickens. Avian pathology : Journal of the W.V.P.A. 16: 61-71.

Julian, R. J., I. McMillan, and M. Quinton, 1989. The effect of cold and dietary energy on right ventricular hypertrophy, right ventricular failure and ascites in meat-type chickens. Avian Pathology. 18: 675-684.

Kalmar, I. D., A. Cools, J. Buyse, P. Roose, and G. P. J. Janssens, 2010: Dietary N,N-dimethylglycine supplementation improves nutrient digestibility and attenuates pulmonary hypertension syndrome in broilers. Journal of Animal Physiology and Animal Nutrition. 94: E339-E347.

Kettunen, H., S. Peuranen, and K. Tiihonen, 2001. Betaine aids in the osmoregulation of duodenal epithelium of broiler chicks, and affects the movement of water across the small intestinal epithelium in vitro. Comparative Biochemistry and Physiology a-Molecular and Integrative Physiology. 129: 595-603.

Krista, L. M., C. W. Carlson, and O. E. Olson, 1961. Some Effects of Saline Waters on Chicks, Laying Hens, Poults, and Ducklings. Poultry Science. 40: 938-944.

Maxwell, M. H., G. W. Robertson, and S. Spence, 1986. Studies on an ascitic syndrome in young broilers. 1. Haematology and pathology. Avian pathology : Journal of the W.V.P.A. 15: 511-24.

Mirsalimi, S. M., P. J. Obrien, and R. J. Julian, 1993. Blood-volume increase in salt-induced pulmonary-hypertension, heart-failure and ascites in broiler and white leghorn chickens. Canadian Journal of Veterinary Research-Revue Canadienne De Recherche Veterinaire. 57: 110113.

Mumma, J. O., J. P. Thaxton, Y. Vizzier-Thaxton, and W. L. Dodson, 2006. Physiological stress in laying hens. Poultry Science. 85: 761-769.

Olkowski, A. A., H. L. Classen, and L. Kumor, 1998. Left atrio-ventricular valve degeneration, left ventricular dilation and right ventricular failure: A possible association with pulmonary hypertension and aetiology of ascites in broiler chickens. Avian Pathology. 27: 51-59.

Olkowski, A. A., H. L. Classen, C. Riddell, and C. D. Bennett, 1997. A study of electrocardiographic patterns in a population of commercial broiler chickens. Veterinary Research Communications. 21: 51-62.

Olkowski, A. A., B. M. Rathgeber, G. Sawicki, and H. L. Classen, 2001. Ultrastructural and molecular changes in the left and right ventricular myocardium associated with ascites syndrome in broiler chickens raised at low altitude. Journal of Veterinary Medicine Series a-Physiology Pathology Clinical Medicine. 48: 1-14.

Pare, W. P., B. Rothfeld, K. E. Isom, and A. Varady, 1973. Cholesterol synthesis and metabolism as a function of unpredictable shock stimulation. Physiology \& behavior. 11: 107-10.

Puvadolpirod, S. and J. P. Thaxton, 2000. Model of physiological stress in chickens 2. Dosimetry of adrenocorticotropin. Poultry Science. 79: 370376.

SAS Institute., 2013. SAS user's giude: version 9.4. SAS Institute Inc., Cary, NC. 
Sayed, M. A. M. and J. Downing, 2011. The effects of water replacement by oral rehydration fluids with or without betaine supplementation on performance, acid-base balance, and water retention of heat-stressed broiler chickens. Poultry Science. 90:157-167.

Sibbald, I. R., W. F. Pepper, and S. J. Slinger, 1962. Sodium Chloride in the Feed and Drinking Water of Chicks. Poultry Science. 41: 541-545.

Siegel, H. S., 1995. Stress, strains and resistance. British Poultry Science. 36: 3-22.

Sokkar, S. M., B. M. Hussein, and M. A. Mohammed, 1983. Renal lesions in baby chicks due to sodium chloride poisoning. Avian pathology : Journal of the W.V.P.A. 12: 277-85.

Stachenfeld, N. S., 2008. Acute Effects of Sodium Ingestion on Thirst and Cardiovascular Function. Current Sports Medicine Reports. 7: S7-S13.

Strange, K., 2004. Cellular volume homeostasis. Advances in Physiology Education, 28: 155-159.

Surwit, R. S.; Schneider, M. S. and Feinglos, M. N., 1992: Stress and diabetes-mellitus. Diabetes Care. 15: 1413-1422.

Teeter, R. G. and T. Belay, 1996. Broiler management during acute heat stress. Animal Feed Science and Technology. 58: 127-142.

Teeter, R. G., J. C. Remus, T. Belay, M. Mooney, E. Virtanen. and P. Augustine, 1999. The effects of betaine on water balance and performance in broilers reared under differing environmental conditions. Proceedings of the $15^{\text {th }}$ Australian
Poultry Science Symposium, Sydney, New South Wales, Australia. 9-10 February 1999.

Verbalis, J. G., 2003. Disorders of body water homeostasis. Best Practice \& Research Clinical Endocrinology \& Metabolism. 17: 471-503.

Vleck, C. M., N. Vertalino, D. Vleck, and T. L. Bucher, 2000. Stress, corticosterone, and heterophil to lymphocyte ratios in free-living Adelie Penguins. Condor. 102: 392-400.

Xiang, R. P., W. D. Sun, K. C. Zhang, J. C. Li, J. Y. Wang, and X. L. Wang, 2004. Sodium chlorideinduced acute and chronic pulmonary hypertension syndrome in broiler chickens. Poultry Science. 83: 732-736.

Zardooz, H., S. Z. Asl, M. K. G. Naseri, and M. Hedayati, 2006. Effect of chronic restraint stress on carbohydrate metabolism in rat. Physiology \& Behavior. 89: 373-378.

Zhang, J., X. Feng, L. Zhao, W. Wang, M. Gao, B. $\mathrm{Wu}$, and J. Qiao, 2013. Expression of hypoxiainducible factor 1 alpha mRNA in hearts and lungs of broiler chickens with ascites syndrome induced by excess salt in drinking water. Poultry Science. 92: 2044-2052.

Zhao, J. P., H. Lin, H. C. Jiao, and Z. G. Song, 2009. Corticosterone suppresses insulin- and NOstimulated muscle glucose uptake in broiler chickens (Gallus gallusdomesticus). Comparative Biochemistry and Physiology C-Toxicology \& Pharmacology. 149:448-454.

\section{تأثيرات الملوحة العالية لمياة الثرب و اضافة البيتين على حدوث حالات ارتفاع ضغط الدم الرئوي في كتاكيت التسمين}

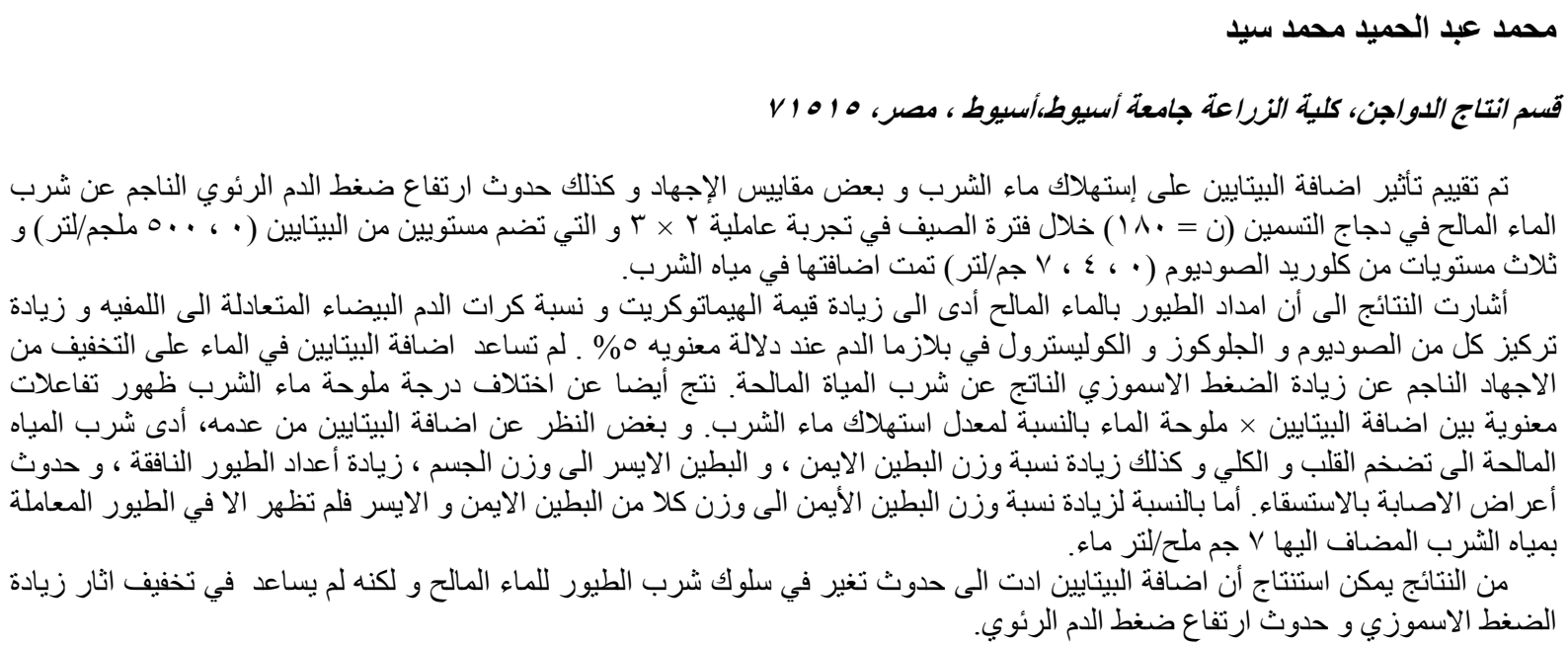

